\title{
A COMPARATIVE PROSPECTIVE STUDY OF THE EFFECTS OF ARV ON LIVER ENZYMES IN HIV POSITIVE PATIENTS WITH HCV CO-INFECTION AND HCV NAÏVE PATIENTS ATTENDING ART CENTRE OF JNIMS, IMPHAL
}

\author{
Ksh. Achouba Singh ${ }^{1}$, Kh. Lokeshwar Singh ${ }^{2}$, M. Umakanta Singh ${ }^{3}$, Ram Kamei $^{4}$
}

${ }^{1}$ Associate Professor, Department of Endocrinology, Jawaharlal Nehru Institute of Medical Sciences, Imphal. 2Associate Professor, Department of Medicine, Jawaharlal Nehru Institute of Medical Sciences, Imphal.

${ }^{3}$ Senior Resident, Department of Medicine, Jawaharlal Nehru Institute of Medical Sciences, Imphal. ${ }^{4}$ Senior Resident, Department of Medicine, Jawaharlal Nehru Institute of Medical Sciences, Imphal.

\section{ABSTRACT}

\section{BACKGROUND}

An appreciably large fraction of the population of Manipur has been diagnosed as HIV/AIDS positive and an increase in the number of patients with HCV co-infection was observed, that led to dilemma of ART initiation at the background of liver problem. This study was taken up to solve such dilemma.

\section{MATERIALS AND METHODS}

A prospective followup of HIV positive cases attending ART Centre of JNIMS Hospital, Porompat, Imphal, Manipur was done among those who were screened for HCV infection and found positive and identical controls who were HCV negative for each HCV positive case from $1^{\text {st }}$ January 2011 to $31^{\text {st }}$ December 2015. During the period, all HCV co-infected cases who were started on ART were followed up every 3 months up to 6 months by selecting comparable HCV negative HIV patients who were similarly started on ART and monitored for changes in ALT level and CD4 count.

\section{RESULTS}

Improvement in ALT levels and CD4 counts were noted in both HCV co-infected and non-HCV co-infected HIV patient groups.

\section{CONCLUSION}

Initiation of ART had significantly better outcome in patients of HIV with low CD4 count whether they were associated with HCV co-infection or not.

\section{KEYWORDS}

HCV Co-infection, HIV, ALT Level, CD4 Count, JNIMS, Imphal, Manipur.

HOW TO CITE THIS ARTICLE: Singh KA, Singh KL, Singh MU et al. A comparative prospective study of the effects of ARV on liver enzymes in HIV positive patients with HCV co-infection and HCV naïve patients attending ART centre of JNIMS, Imphal. J. Evolution Med. Dent. Sci. 2016;5(76):5606-5609, DOI: 10.14260/jemds/2016/1265

\section{INTRODUCTION}

Manipur is a small Indian state in the eastern corner adjoining Myanmar and the first Human Immunodeficiency Virus (HIV) positive case was reported in February 1990 from the blood samples of October 1989 among a cluster of Injecting Drug Users (IDUs). ${ }^{1}$ HIV co-infections with Hepatitis B virus (HBV) and Hepatitis $\mathrm{C}$ virus (HCV) is high in the state of Manipur as shown by Saha et al (2000) $)^{2}$ and Devi Kh S et al (2005). ${ }^{3}$ Highly active antiretroviral therapy (HAART) in Human Immunodeficiency Virus (HIV) infected patients has led to dramatic improvements both in morbidity and mortality but co-infected people die from HCV related complications, like liver cirrhosis or liver cancer (Nelson Lancet 2011). Antiretroviral (ARV) drugs have been associated with both short and long term toxicities including hepatotoxicity, which may be life threatening. ${ }^{4}$

Financial or Other, Competing Interest: None.

Submission 27-08-2016, Peer Review 12-09-2016,

Acceptance 14-09-2016, Published 20-09-2016.

Corresponding Author:

Dr. Ksh. Achouba Singh,

Uripok Bachaspati Maning Leikai,

Imphal-795001, Manipur.

E-mail: drachoubasingh@yahoo.com

DOI: $10.14260 /$ jemds $/ 2016 / 1265$

\section{(c) $(1) \odot$}

All major classes of antiretroviral therapy (ART) have been described to be associated with elevations in serum hepatic enzymes. ${ }^{5}$ As HIV-infected patients live longer, they develop long term manifestations of chronic HIV infection and treatment complication. ${ }^{6}$ The severity of ART may range from the absence of symptoms to liver decompensation and the outcome ranges from spontaneous resolution to liver failure and death. ${ }^{7}$

In the resource poor setting, Alanine aminotransferase (ALT) and Aspartate aminotransferase (AST) is an ideal marker of hepatocellular injury. ${ }^{8}$ Studies have revealed that $14-20 \%$ of adults on ART had elevated serum liver enzymes as a marker of hepatocellular injury. ${ }^{9}$ Chronic hepatitis B and C infections are the most well-established risk factors for liver enzyme elevations.6,10 There is a lack of information from the region on the extent of ART related hepatotoxicity associated with or without hepatitis $C$ virus. The purpose of this study was to determine hepatotoxicity by using serum alanine aminotransferase levels as markers in HIV-infected patients receiving ART in association with a very important risk factor i.e. hepatitis $\mathrm{C}$ co-infection and also compare with HCV naïve or those without HCV infection.

\section{MATERIAL AND METHOD}

Data: A prospective followup of HIV positive cases attending ART Centre of JNIMS Hospital, Porompat, Imphal, Manipur was 
done among those who were screened for HCV infection and found positive and identical controls who were HCV negative for each HCV positive case, from $1^{\text {st }}$ January 2011 to $31^{\text {st }}$ December 2015. During the period all HCV co-infected cases who were started on ART were followed up every 3 months up to 6 months. Control group of HIV cases on ART but without HCV infection were similarly assessed at 3 months interval up to 6 months. During the study period, there were 110 cases of HCV co-infection and equal number of HCV negative HIV infected cases were included in the control group.

\section{METHOD}

All the cases after Pre-ART enrolment were worked up for CD4 count, HBsAg, HCV Ab, routine blood count, chest radiograph, renal and liver functions. Based on the CD4 levels, antiretroviral therapy (ART) was started and CD4 count repeated at 6 months. Since the study area was in resource poor setting, only Alanine aminotransferase (ALT) level was followed up at 3 months and 6 months after initiation of ART.

ERS system as prescribed by National AIDS Control Organization (NACO) was used for detecting HIV infection. Antibody test (ELISA) for Hepatitis C Virus (HCVAb) was done for screening HCV infection. Alanine aminotransferase (ALT) was determined by autoanalyser (Dry Chemistry method). CD4+ count was done using FACS counter. Normal value for ALT (SGPT) at $37^{\circ} \mathrm{C}: 0-40 \mathrm{IU} / \mathrm{L}$ was taken for both Women and Men. Commonly used grading system developed by the Acquired Immune Deficiency Syndrome (AIDS) Clinical Trials Group (CTG) was utilised to analyze the toxicity levels of liver enzymes. ${ }^{11}$

Toxicity of Degree 0: The level of toxicity which is considered as normal in which its value is $<1.25 \times$ normal value of ALT in serum.

Toxicity of Degree 1: The level of toxicity which is considered as weak in which its value is $1.26-2.5 \times$ normal value of ALT in serum.

Toxicity of Degree 2: The level of toxicity which is considered as moderate in which its value is $2.6-5 \times$ normal value of ALT in serum.

Toxicity of Degree 3: The level of toxicity which is considered as severe in which its value is $5.1-10 \times$ normal value of ALT in serum.

Toxicity of Degree 4: The level of toxicity which is considered as severe in which its value is $>10 \times$ normal value of ALT in serum.

\section{Ethical Considerations}

The present study had clearance from ethical committee of Jawaharlal Nehru Institute of Medical Sciences, Imphal as this study was not going to involve any intervention that could have produced adverse reactions even though the study was a prospective study. All the treatments were done according to protocol based NACO guidelines for initiation of ART. Emphasis to maintain confidentiality was strictly followed as per guideline given by the ethic committee.

\section{Statistical Analysis}

All the statistical analysis was done by calculating mean and standard deviation for variables that were normally distributed; the median and averages were used to calculate the variables which are not distributed uniformly. To calculate proportions, t-test, Chi-square statistics were used and a $\mathrm{p}$ value less than 0.05 was considered statistically significant. We utilised percentage to interpret suitable data. All the statistical analysis was done using SPSS Version 16 software.

\section{RESULTS}

There were differences in the baseline ALT levels of the HCV positive HIV cases and HCV negative HIV patients who were taken as controls. However, we have chosen the most identical baseline characteristics as the control group.

At 3 months followup, there were improvements in ALT levels of both cases and controls as evident from reduction in number of patients who had moderate-to-severe hepatotoxicity (Grade 2 and Grade 3). In HCV positive HIV positive group, the reduction was 1 out of 10 patients which was $10 \%$ and in HCV negative HIV positive group the reduction was 1 out of 8 patients who had ALT levels at moderate-tosevere hepatotoxicity, the reduction in this group was $12.5 \%$ [Table-1] [Table-2].

At 6 months, the improvement in ALT levels of both HCV positive and HCV negative groups of HIV patients after initiation of ART were remarkable. HCV positive HIV patients, whose baseline ALT levels were in the moderate-to-severe hepatotoxicity (Grade 2 and 3), reduced to 7 from 10 patients, which is about $30 \%$ reduction. Patients who were levelled with moderate-to-severe hepatotoxicity (Grade 2 and 3) before initiation of ART among HCV negative HIV positive group were reduced to 6 from 8 patients, after 6 months of ART initiation. This reduction in ALT level in the control group was about $25 \%$.

\begin{tabular}{|c|c|c|c|c|}
\hline Followup Months & ALT Range in IU & HCV & Without HCV & p-value \\
\hline At initiation(0) & $(0-50)$ & 66 & 79 & 0.305 \\
\hline & $(51-100)$ & 34 & 23 & \\
\hline & $(101-200)$ & 7 & 3 & 0.039 \\
\hline & $(>=201)$ & 3 & 82 & \\
\hline At 3 months(3) & $(0-50)$ & 63 & 6 & 0.705 \\
\hline & $(51-100)$ & 38 & 72 & 32 \\
\hline \\
\hline
\end{tabular}




\begin{tabular}{|c|c|c|c|c|c|c|c|c|}
\hline & \multirow{2}{*}{$\begin{array}{c}\text { HCV + } \\
\text { m + S.D. }\end{array}$} & \multirow{2}{*}{$\begin{array}{c}\text { HCV - } \\
\mathrm{m}+\text { S.D. }\end{array}$} & \multirow{2}{*}{$\begin{array}{c}\text { Mean } \\
\text { Difference }\end{array}$} & \multirow[t]{2}{*}{ SE diff } & \multicolumn{2}{|c|}{$\begin{array}{l}\text { 95\% C.I. of the } \\
\text { Difference }\end{array}$} & \multirow[t]{2}{*}{$\mathbf{t}$} & \multirow[t]{2}{*}{ p-value } \\
\hline & & & & & Lower & Upper & & \\
\hline ALT $(0)$ & $56.68+48.3$ & $49.28+47.98$ & 7.4 & 6.488 & -5.388 & 20.188 & 1.141 & 0.255 \\
\hline ALT (3) & $57.75+45.8$ & $44.3+31.5$ & 13.473 & 5.297 & 3.033 & 23.913 & 2.543 & 0.012 \\
\hline ALT (6) & $50.6+29.03$ & $43.99+20.0$ & 6.609 & 6.609 & -1.103 & 14.321 & 1.689 & 0.093 \\
\hline & Tab & hanges & ositive & CVne & Cases & Patient & & \\
\hline
\end{tabular}

There were 81 patients who had CD4 count less than $200 /$ cu.mm among the HCV positive HIV patients at the time of initiation of ART, and at 6 months after initiation of ART the number of patients having CD4 count less than 200/cu.mm were reduced to 13 patients and majority of the patients i.e. 68 of them had shown improvement in CD4 count above $200 /$ cu.mm, which was approximately $84 \%$ [Table-3] [Table4].

Among the HCV negative HIV positive patients, there were 91 patients with CD4 count less than 200/cu.mm at the time of initiation of ART, and at 6 months after initiation of ART 82 patients had improved to CD 4 count above 200 /cu.mm, which was about $90 \%$, a remarkable improvement in CD4 count was recorded.

\begin{tabular}{|c|c|c|c|c|}
\hline $\begin{array}{c}\text { Followup } \\
\text { in } \\
\text { Month }\end{array}$ & $\begin{array}{c}\text { CD4 } \\
\text { Counts } \\
\text { in } \\
\text { Cells/ } \\
\text { cu.mm }\end{array}$ & $\begin{array}{c}\text { HCV } \\
\text { Positive } \\
\text { Cases }\end{array}$ & $\begin{array}{c}\text { HCV } \\
\text { Negative } \\
\text { Cases }\end{array}$ & $\begin{array}{c}\text { p- } \\
\text { value }\end{array}$ \\
\hline $\begin{array}{c}\text { At } \\
\text { initiation }\end{array}$ & $<=200$ & 81 & 91 & 0.141 \\
\hline & $>=201$ & 29 & 19 & \\
\hline $\begin{array}{c}\text { At } 6 \\
\text { months }\end{array}$ & $<=200$ & 13 & 9 & 0.369 \\
\hline & $>=201$ & 97 & 101 & \\
\hline
\end{tabular}

\begin{tabular}{|c|c|c|c|c|c|c|c|c|}
\hline & HCV + & HCV - & Mean & SE & 95\% C.I. of the Difference & \multirow{2}{*}{ t } & \multirow{2}{*}{ p-value } \\
\cline { 6 - 7 } & m + S.D. & m + S.D. & Difference & diff & Lower & Upper & & \\
\hline CD4+ (0) & $159.8+114.9$ & $148.6+165.4$ & 11.245 & 19.206 & -26.807 & 49.098 & 0.586 & 0.559 \\
\hline CD4+ (6) & $515.8+281.6$ & $657+364.6$ & -141.427 & 43.92 & -227.988 & -54.366 & -3.220 & 0.001 \\
\hline
\end{tabular}

\section{DISCUSSION}

In this study, we had seen a remarkable improvement in the levels of alanine amino transferase (ALT) after initiation of ART in subsequent followup at 3 months and 6 months.

At 3 months followup, there were improvements in ALT levels of both cases and controls as evident from reduction in number of patients who had moderate-to-severe hepatotoxicity (Grade 2 and Grade 3). And similar trend of improvements in ALT level were also documented in the followup at 6 months after initiation of ART [Table-1], HCV positive HIV patients whose baseline ALT levels were in the moderate-to-severe hepatotoxicity (Grade 2 and 3 ) reduced to 7 from 10 patients, which is about $30 \%$ reduction. Patients who were levelled with moderate-to-severe hepatotoxicity (Grade 2 and 3) before initiation of ART among HCV negative HIV positive group were reduced to 6 from 8 patients after 6 months of ART initiation. This reduction in ALT level in the control group was about $25 \%$. Similar findings were also documented in few studies done in different parts of the world,12,13,14,15 and contradictory findings were also documented in various studies from different parts of the globe. $4,5,6,7,8,16,17$

Among the HCV positive HIV patients at the time of initiation of ART and at 6 months after initiation of ART, approximately $84 \%$ of the patients having CD4 count less than 200/cu.mm had improved and crossed CD4 count above 200/cu.mm, which shows a remarkable improvement, these findings were supported by various studies done in different parts of the world. ${ }^{12,13,14,15}$ And among the HCV negative HIV positive patients, the improvement in CD4 counts after 6 months of initiation of ART were marked by about $90 \%$ of the patients crossing CD4 count above 200/cu.mm from pre-ART
CD4 count below 200/cu.mm, similar finding is universal and is the basis for ART.18

\section{CONCLUSION}

Initiation of ART had significant outcome in patients of HIV with low CD4 count whether they were associated with HCV co-infection or not. The study documented improvement in liver enzyme ALT levels in both HCV co-infection group and non-HCV co-infection group after initiation of ART. CD4 count also improved in both the groups in very remarkable manner. However, further studies need to be done in this area for better and timely management of patients with HIV.

\section{REFERENCES}

1. http://manipursacs.nic.in/history.html 2016.

2. Saha MK, Chakrabarti S, Panda S, et al. Prevalence of HCV \& HBV infection amongst HIV seropositive intravenous drug users \& their non-injecting wives in Manipur, India. Indian J Med Res 2000;111:37-9.

3. Devi KhS, Brajachand N, Singh HL, et al. Co-infection by human immune deficiency virus, hepatitis B and hepatitis $\mathrm{C}$ virus in injecting drug users. J Commun Dis 2005;37(1):73-7.

4. Kalyesubula R, Kagimu M, Opio KC, et al. Hepatotoxicity from first line antiretroviral therapy: an experience from a resource limited setting. Afr Health Sci 2011;11:16-23.

5. Mankhatithan W, Lueangniyomkul A, Manosuthin W. Hepatotoxicity in patients co-infected with tuberculosis and HIV-1 while receiving non-nucleoside reverse transcriptase inhibitors based antiretroviral therapy and rifampicin containing anti-tuberculosis regimen. Southeast Asian J Trop Med Public Health 2011;42(3):651-8. 
6. Sulkowski MS. Drug-induced liver injury associated with antiretroviral therapy that includes HIV-1 protease inhibitors. Clin Infect Dis 2004;38(Suppl 2):S90-7.

7. Emejulu AA, Ujowundu CO, Igwe CU, et al. Hepatotoxicity of antiretroviral drugs in HIV seropositive Nigerian Patients. Aust J Basic and App Sci 2010;4:4275-8.

8. Eluwa G, Badru T, Akpoigbeu KJ, et al. Adverse drug reactions to antiretroviral therapy (ARV): incidence, type and risk factors in Nigeria. BMC Clin Pharmacol 2012;12:1-9.

9. Puoti M, Nasta P, Gatti F, et al. HIV-related liver disease: ARV drugs, coinfection and other risk factors. JIAPAC (Chic) 2009;8(1):30-42.

10. Shores NJ, Maida I, Perez-Saleme L, et al. Virological rather than host factors are associated with transaminase levels among HIV/HCV co-infected patients. J Int Assoc Physicians AIDS Care (Chic) 2010;9(1):15-9.

11. AIDS clinical trials group, table of grading severity of adult adverse experiences, division of AIDS, national institute of allergy and infectious diseases, Rockville, Md, USA, 1996.

12. Price JC, Seaberg EC, Phair JP, et al. Brief report: highly active antiretroviral therapy mitigates liver disease in HIV infection. J Acquir Immune Defic Syndr 2016;72(3): 319-23.

13. Ocama P, Castelnuovo B, Kamya MR, et al. Low frequency of liver enzyme elevation in HIV-infected patients attending a large urban treatment centre in Uganda. Int J STD AIDS 2010;21(8):553-7.
14. Kovari $H$, Ledergerber $B$, Battegay $M$, et al. Incidence and risk factors for chronic elevation of alanine aminotransferase levels in HIV-infected persons without hepatitis B or C virus co-infection. Clinical Infectious Diseases 2010;50(4):502-11.

15. So-Armah KA, Chang J, Alcorn C, et al. HIV Infection, antiretroviral therapy initiation and longitudinal changes in biomarkers of organ function. Curr HIV Res 2014;12(1):50-9.

16. Nagu TJ, Kanyangarara M, Hawkins $C$, et al. Elevated alanine aminotransferase in antiretroviral-naïve HIVinfected African patients: magnitude and risk factors. HIV Med 2012;13(9):541-8.

17. Kovari H, Sabin CA, Ledergerber B, et al. Antiretroviral drugs and risk of chronic ALT elevation in HIVmonoinfected persons: the D:A:D study. Open Forum Infectious Diseases 2016.

18. Jain C, Khatri AK, Yesikar V, et al. A cross sectional study to find out the efficacy of prevention of parent to child transmission services providing centers of Indore division. Int J Community Med Public Health 2016;3(6):1404-8. India HIV estimate by NACO, 2015.

http://www.naco.gov.in/upload/2015\%20MSLNS/HSS/I ndia\%20HIV\%20Estimations\%202015. pdf. 